\title{
Adjusted Anion Gap Is Associated with Glomerular Filtration Rate Decline in Chronic Kidney Disease
}

\author{
Akashi Togawa $^{a}$ Satoko Uyama ${ }^{a}$ Seiko Takanohashi ${ }^{a}$ \\ Megumi Shimasaki ${ }^{a}$ Takehiko Miyaji $^{b}$ Hiroyuki Endo $^{c}$ \\ Yoshihide Fujigakid, e \\ a Department of Nephrology, Shizuoka Saiseikai General Hospital, bMiyaji Clinic, and \\ 'Tanpopo Clinic, Shizuoka, dinternal Medicine 1, Hamamatsu University School of Medicine, \\ Hamamatsu, and ${ }^{\mathrm{e} D i v i s i o n}$ of Nephrology, Department of Internal Medicine, \\ Teikyo University School of Medicine, Tokyo, Japan
}

\section{Key Words}

Chronic kidney disease $\cdot$ Glomerular filtration rate decline $\cdot$ Adjusted anion gap

\section{Abstract}

Background: Metabolic acidosis is known to accelerate the progression of chronic kidney disease (CKD). However, whether undetermined anions as indicated by the adjusted anion gap $(\mathrm{aAG})$ are associated with estimated glomerular filtration rate (eGFR) decline in patients with CKD is unclear. Methods: Data from 42 patients with CKD (baseline eGFR, 7.1-52.0 ml/min/ $1.73 \mathrm{~m}^{2}$ ) without massive proteinuria (urinary protein-creatinine ratio, UPCR $<3.5$ ) were retrospectively analyzed. aAG was calculated from serum sodium, serum chloride, serum bicarbonate, serum albumin, serum potassium, serum calcium and serum phosphate. The association between the percentage of the 6 -month change of eGFR (\% $\triangle \mathrm{eGFR} / 6 \mathrm{~m})$ and aAG was examined. Results: The mean baseline eGFR was $27.5 \pm 11.1 \mathrm{ml} / \mathrm{min} / 1.73 \mathrm{~m}^{2}$ and the mean $\% \triangle \mathrm{eGFR} / 6 \mathrm{~m}$ was $13.8 \pm 10.3$. UPCR and aAG were $1.13 \pm 0.93$ and $9.48 \pm 1.88$, respectively. $\% \triangle \mathrm{eGFR} / 6 \mathrm{~m}$ was associated with aAG $(r=0.438, p<0.005)$, but not with UPCR $(r=0.194$, $p=0.218)$. In multivariate linear regression analyses, aAG remained significantly associated with $\% \triangle \mathrm{eGFR} / 6 \mathrm{~m}(\beta=0.45, \mathrm{p}<0.01)$ after controlling for age, baseline eGFR, UPCR and $\mathrm{HCO}_{3}^{-}$ concentration. Conclusion: These data suggest that aAG appears to be associated with the progression of CKD. aAG might be an independent predictor of CKD progression.

The results presented in this paper have not been published previously in whole or in part, except in abstract form. 
Togawa et al.: Adjusted Anion Gap Is Associated with Glomerular Filtration Rate Decline in Chronic Kidney Disease

\section{Introduction}

Anions accumulate during the course of chronic kidney disease (CKD) [1-3], and unmeasured anions such as indoxyl sulfate and $p$-cresyl sulfate reportedly accelerate CKD progression [4] and complications [5, 6]. However, whether the net amount of unmeasured anions is associated with CKD progression has not been elucidated. The level of unmeasured anions can be estimated by the classical anion gap (AG) or the adjusted AG (aAG). aAG is calculated from electrolytes including serum sodium, chloride, potassium, calcium, phosphate, bicarbonate and serum albumin. aAG has been considered to reveal the level of undetermined anions more precisely than the classical AG [7].

The present study investigated whether aAG is associated with estimated glomerular filtration rate (eGFR) declines in CKD patients. Associations between aAG and other known risk factors for eGFR decline were also studied.

\section{Subjects and Methods}

\section{Study Population}

The subjects enrolled were outpatients treated at the Department of Nephrology of Shizuoka Saiseikai General Hospital between June 2010 and November 2012. Forty-one adults with an eGFR7 of $-52 \mathrm{ml} / \mathrm{min} / 1.73 \mathrm{~m}^{2}$ and a urinary protein-creatinine ratio (UPCR) of $<3.5$ were included. The study protocols were approved by the Ethics Committee of Shizuoka Saiseikai General Hospital (No. 24-8-02).

\section{Data Collection}

Serum chemistry values were determined with Toshiba C1 16200 and C1 8260, and serum bicarbonate values were measured from venous blood samples using the Radiometer ABL 730 analyzer. Surshield PREZA-PAK (Terumo, Tokyo, Japan) was used for venous bicarbonate measurement. For bicarbonate measurement, all blood samples were filled in tubes without air and injected into the analyzer within 6-10 min after blood collection. Venous bicarbonate values were adjusted to the arterial bicarbonate values according to the following formula: adjusted bicarbonate = venous bicarbonate -1.5 [8]. Using the equation established by the Japanese Society of Nephrology, eGFR was calculated from serum creatinine (mg/dl), age and sex [9]. Baseline eGFR and eGFR after 6 months were defined as eGFR ${ }_{0}$ and eGFR $_{6}$, respectively. As previously reported, the percentage of the 6-month change of eGFR $(\% \Delta \mathrm{eGFR} / 6 \mathrm{~m})$ was defined as $\% \Delta \mathrm{eGFR} / 6 \mathrm{~m}=100 \times\left(\mathrm{eGFR}_{0}-\mathrm{eGFR}_{6}\right) / \mathrm{eGFR}_{0}[10,11]$. aAG was calculated using the formula modified from a previous report [7]: $\mathrm{aAG}=$ serum sodium $(\mathrm{mEq} / \mathrm{l})$ - serum chloride $(\mathrm{mEq} / \mathrm{l})$ - adjusted serum bicarbonate $(\mathrm{mEq} / \mathrm{l})-2.5 \times$ serum albumin $(\mathrm{g} / \mathrm{dl})+$ serum potassium $(\mathrm{mEq} / \mathrm{l})+0.5 \times$ total calcium $(\mathrm{mg} / \mathrm{dl})-[0.323 \times$ serum phosphate $(\mathrm{mg} / \mathrm{dl})] \times 1.8$.

\section{Statistical Analysis}

R (http://www.r-project.org/) was used for all statistical analyses. Relationships between $\% \Delta \mathrm{eGFR} / 6 \mathrm{~m}$, aAG and UPCR were examined by the Pearson correlation analysis. Multiple linear regression analyses were used to examine associations between aAG and $\% \Delta \mathrm{eGFR} / 6 \mathrm{~m}$ by controlling for age, UPCR, initial eGFR ( $\left.\mathrm{eGFR}_{0}\right)$ and adjusted bicarbonate concentration. 
Fig. 1. Correlation between $a A G$ and $\% \Delta \mathrm{eGFR} / 6 \mathrm{~m}$. aAG showed a significant association with $\% \Delta \mathrm{eGFR} / 6 \mathrm{~m} \quad \mathrm{r}=0.438, \mathrm{p}<$ $0.005)$.

Table 1. Patient characteristics $(n=42)$
Togawa et al.: Adjusted Anion Gap Is Associated with Glomerular Filtration Rate Decline in Chronic Kidney Disease

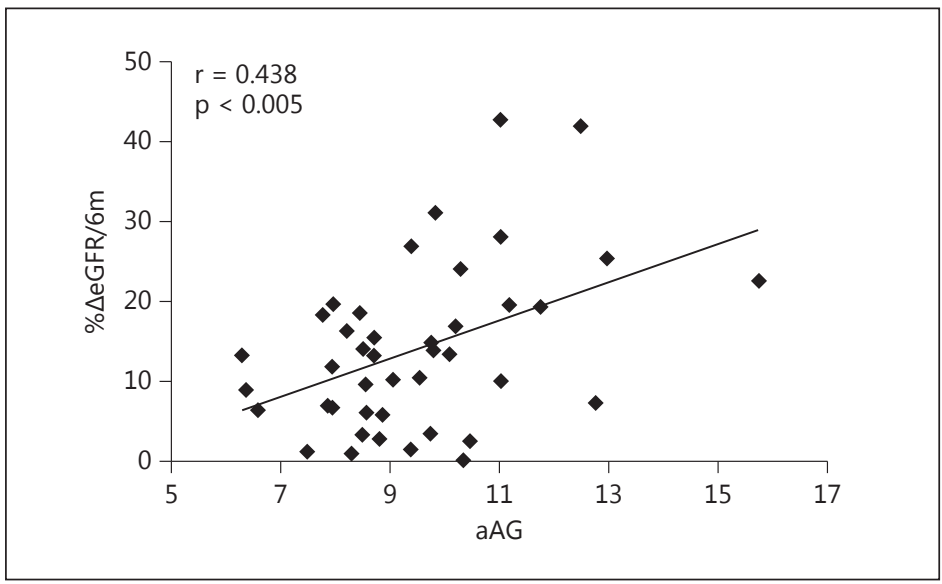

$\begin{array}{lc}\text { Age, years } & 68 \pm 12.7 \\ \text { Diabetic nephropathy, \% } & 9.5 \\ \text { eGFR }_{0}, \mathrm{ml} / \mathrm{min} / 1.73 \mathrm{~m}^{2} & 27.5 \pm 11.1 \\ \mathrm{eGFR}_{6}, \mathrm{ml} / \mathrm{min} / 1.73 \mathrm{~m}^{2} & 23.3 \pm 10.8 \\ \% \Delta \mathrm{eGFR} / 6 \mathrm{~m} & 13.8 \pm 10.3 \\ \text { UPCR } & 1.13 \pm 0.93 \\ \text { Serum albumin, g/dl } & 4.1 \pm 0.4 \\ \text { Adjusted } \mathrm{HCO}_{3}^{-}, \mathrm{mEq} / \mathrm{l} & 22.4 \pm 2.9 \\ \text { aAG } & 9.48 \pm 1.88\end{array}$

Values are means \pm SD, unless otherwise specified.

\begin{tabular}{lrc}
\hline & $\beta$ & $p$ value \\
\hline aAG & 0.45 & $<0.01$ \\
Age (years) & 0.18 & 0.27 \\
UPCR & 0.12 & 0.49 \\
eGFR $_{0}\left(\mathrm{ml} / \mathrm{min} / 1.73 \mathrm{~m}^{2}\right)$ & -0.03 & 0.90 \\
$\mathrm{HCO}_{3}^{-}(\mathrm{mEq} / \mathrm{l})$ & 0.13 & 0.44 \\
\hline
\end{tabular}

Table 2. Multiple linear regression analysis of $\% \Delta \mathrm{eGFR} / 6 \mathrm{~m}$

\section{Results}

Table 1 shows the characteristics of the patients participating in this study. The percentage of patients with diabetes was 9.5. The mean ( \pm standard deviation) baseline eGFR ( $\mathrm{eGFR}_{0}$ ) was $27.5 \pm 11.1 \mathrm{ml} / \mathrm{min} / 1.73 \mathrm{~m}^{2}$ (range, 7.1-52.0), $\% \Delta \mathrm{eGFR} / 6 \mathrm{~m}$ was $13.8 \pm 10.3$ and aAG was $9.48 \pm 1.88$. The association between $\% \Delta \mathrm{eGFR} / 6 \mathrm{~m}$, UPCR and aAG was examined. aAG $(\mathrm{r}=$ $0438, \mathrm{p}<0.005$ ) was significantly associated with $\% \Delta \mathrm{eGFR} / 6 \mathrm{~m}$ (fig. 1 ), whereas UPCR was not $(\mathrm{r}=0.193, \mathrm{p}=0.22)$. In multiple linear regression analysis, the association between $\% \Delta \mathrm{eGFR} / 6 \mathrm{~m}$ and aAG remains significant $(\beta=0.45, \mathrm{p}<0.01)$ after controlling for age, UPCR, $\mathrm{eGFR}_{0}$ and serum bicarbonate concentration (table 2). 


\section{Discussion}

The present study demonstrated an association between aAG and the eGFR decline in CKD patients. Compared with other possible predictors, aAG appears to be an independent predictor of CKD progression.

An increase in the AG in pre-end-stage to end-stage CKD has been reported [1], but the relationship between GFR and AG is not fully understood. Levels of certain uremic toxins such as indoxyl sulfate and $p$-cresyl sulfate are increased in CKD patients $[12,13]$. These molecules are associated with CKD complications such as vascular endothelial damage [14] or tubular epithelial damage [4], cardiovascular events [5], CKD progression [15] and mortality [6]. In CKD patients, elevated aAG values indicate an increase in the net amount of undetermined anions, including certain uremic toxins. The precise relationship between anionic uremic toxins and $\mathrm{AAG}$ is unclear. However, the evaluation of the net amount of undetermined anions by aAG might provide new information on CKD progression compared with the evaluation of each of the well-known uremic toxins.

Uremic toxins are accumulated in CKD patients; however, the concentration of uremic toxins does not correlate with eGFR [16]. Not only GFR, but also tubular secretion and reabsorption are considered to have an important role in renal clearance of uremic toxins [17]. aAG might be utilized for evaluating the accumulation of uremic toxins in the course of CKD.

aAG is altered and associated with mortality in early CKD patients [18]. This report by Abramowitz et al. [18], together with the present findings, indicates that the net amount of unmeasured anions seems to play an important role in both CKD progression and complications.

Serum bicarbonate levels are associated with mortality in CKD patients [19]. Correction of acidemia by alkali therapy might prevent CKD progression and complications such as volume overload or vascular calcifications $[3,20]$. Making efforts to decrease the levels of undetermined anions is another approach to correcting acidemia in CKD. Oral activated charcoal adsorbent (AST-120) might decrease anionic uremic toxins in CKD patients. In animal models, AST-120 has been reported to decrease the levels of indoxyl sulfate and to prevent the progression of CKD complications [21] and atherosclerosis accelerated by kidney disease [22]. Studies examining the impact of AST-120 on the alteration of aAG and CKD progression are needed.

In conclusion, we demonstrated an association between aAG and the eGFR decline. aAG during the course of CKD may be an important risk factor for CKD progression, and new therapeutic strategies focusing on aAG might be useful to prevent CKD progression.

\section{References}

1 DuBose TD Jr: Acid-base physiology in uremia. Artif Organs 1982;6:363-369.

-2 Ray S, Piraino B, Chong TK, el-Shahawy M, Puschett JB: Acid excretion and serum electrolyte patterns in patients with advanced chronic renal failure. Miner Electrolyte Metab 1990;16:355-361.

-3 Kraut JA, Kurtz I: Metabolic acidosis of CKD: diagnosis, clinical characteristics, and treatment. Am J Kidney Dis 2005;45:978-993.

-4 Kawakami T, Inagi R, Wada T, Tanaka T, Fujita T, Nangaku M: Indoxyl sulfate inhibits proliferation of human proximal tubular cells via endoplasmic reticulum stress. Am J Physiol Renal Physiol 2010;299:F568F576.

5 Niwa T: Role of indoxyl sulfate in the progression of chronic kidney disease and cardiovascular disease: experimental and clinical effects of oral sorbent AST-120. Ther Apher Dial 2011;15:120-124.

6 Barreto FC, Barreto DV, Liabeuf S, Meert N, Glorieux G, Temmar M, Choukroun G, Vanholder R, Massy ZA: Serum indoxyl sulfate is associated with vascular disease and mortality in chronic kidney disease patients. Clin J Am Soc Nephrol 2009;4:1551-1558.

7 Adrogue HJ, Gennari FJ, Galla JH, Madias NE: Assessing acid-base disorders. Kidney Int 2009;76:12391247. 
8 Gokel Y, Paydas S, Koseoglu Z, Alparslan N, Seydaoglu G: Comparison of blood gas and acid-base measurements in arterial and venous blood samples in patients with uremic acidosis and diabetic ketoacidosis in the emergency room. Am J Nephrol 2000;20:319-323.

-9 Matsuo S, Imai E, Horio M, Yasuda Y, Tomita K, Nitta K, Yamagata K, Tomino Y, Yokoyama H, Hishida A: Revised equations for estimated GFR from serum creatinine in Japan. Am J Kidney Dis 2009;53:982-992.

10 Clark WF, Macnab JJ, Sontrop JM, Jain AK, Moist L, Salvadori M, Suri R, Garg AX: Dipstick proteinuria as a screening strategy to identify rapid renal decline. J Am Soc Nephrol 2011;22:1729-1736.

11 Matsushita K, Selvin E, Bash LD, Franceschini N, Astor BC, Coresh J: Change in estimated GFR associates with coronary heart disease and mortality. J Am Soc Nephrol 2009;20:2617-2624.

12 Atoh K, Itoh H, Haneda M: Serum indoxyl sulfate levels in patients with diabetic nephropathy: relation to renal function. Diabetes Res Clin Pract 2009;83:220-226.

-13 Liabeuf S, Barreto DV, Barreto FC, Meert N, Glorieux G, Schepers E, Temmar M, Choukroun G, Vanholder R, Massy ZA: Free $p$-cresylsulphate is a predictor of mortality in patients at different stages of chronic kidney disease. Nephrol Dial Transplant 2010;25:1183-1191.

14 Meijers BK, Van Kerckhoven S, Verbeke K, Dehaen W, Vanrenterghem Y, Hoylaerts MF, Evenepoel P: The uremic retention solute $p$-cresyl sulfate and markers of endothelial damage. Am J Kidney Dis 2009;54:891901.

15 Niwa T, Ise M: Indoxyl sulfate, a circulating uremic toxin, stimulates the progression of glomerular sclerosis. J Lab Clin Med 1994;124:96-104.

16 Eloot S, Schepers E, Barreto DV, Barreto FC, Liabeuf S, Van Biesen W, Verbeke F, Glorieux G, Choukroun G, Massy Z, Vanholder R: Estimated glomerular filtration rate is a poor predictor of concentration for a broad range of uremic toxins. Clin J Am Soc Nephrol 2011;6:1266-1273.

17 Vanholder R, Eloot S, Schepers E, Neirynck N, Glorieux G, Massy Z: An obituary for GFR as the main marker for kidney function? Semin Dial 2012;25:9-14.

18 Abramowitz MK, Hostetter TH, Melamed ML: The serum anion gap is altered in early kidney disease and associates with mortality. Kidney Int 2012;82:701-709.

19 Navaneethan SD, Schold JD, Arrigain S, Jolly SE, Wehbe E, Raina R, Simon JF, Srinivas TR, Jain A, Schreiber MJ Jr, Nally JV Jr: Serum bicarbonate and mortality in stage 3 and stage 4 chronic kidney disease. Clin J Am Soc Nephrol 2011;6:2395-2402.

20 de Brito-Ashurst I, Varagunam M, Raftery MJ, Yaqoob MM: Bicarbonate supplementation slows progression of CKD and improves nutritional status. J Am Soc Nephrol 2009;20:2075-2084.

-21 Fujii H, Nishijima F, Goto S, Sugano M, Yamato H, Kitazawa R, Kitazawa S, Fukagawa M: Oral charcoal adsorbent (AST-120) prevents progression of cardiac damage in chronic kidney disease through suppression of oxidative stress. Nephrol Dial Transplant 2009;24:2089-2095.

-22 Yamamoto S, Zuo Y, Ma J, Yancey PG, Hunley TE, Motojima M, Fogo AB, Linton MF, Fazio S, Ichikawa I, Kon V: Oral activated charcoal adsorbent (AST-120) ameliorates extent and instability of atherosclerosis accelerated by kidney disease in apolipoprotein E-deficient mice. Nephrol Dial Transplant 2011;26:2491-2497. 